\title{
Housing, Finance, Policy and the Wider Economy
}

\author{
Sabine Winkler ${ }^{1}$ \\ ${ }^{1}$ WHU-Otto Beisheim School of Management, Vallendar, Germany \\ Correspondence: Sabine Winkler, WHU-Otto Beisheim School of Management, Allianz Endowed Chair of \\ Finance, 56179 Vallendar, Germany. Tel: 49-261-6509-0. E-mail: sabine.winkler@whu.edu
}

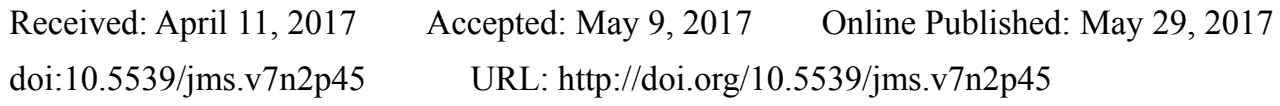

\begin{abstract}
Building an understanding of the complex dynamics between housing, finance, policy and the wider economy is a critical step towards the development of a strategy that permits policy makers to leverage resources and enable the housing market to function better in the pursuit of economic, financial and social objectives. Powerful real, legislative and financial circuits suggest that an enabling strategy for housing can support societal progress and wellbeing. By summarizing the key findings in the existing theoretical and empirical literature, this study helps to explain the complex interrelations between housing, finance, policy and the wider economy by using a simple model; it also deals with housing-related policies and their effects, examines the rational for housing market regulation, investigates whether housing market corrections threaten financial and macroeconomic stability, and asks whether policies are efficacious at controlling housing market outcomes. The important takeaways from this study are: (i) policy setting should be evidence-based, which necessitates further efforts to address existing data deficiencies; (ii) finance trends are in flux and policy effects can be asymmetric, which necessitates regular and critical housing market reviews to identify misallocation, dislocation and reform needs; (iii) improvement in the functioning of the housing market requires a coordinating authority that takes steps to reconcile the various housing market stakeholders' mutually incompatible interests and arrange for concerted policy and institutional reforms. The study closes with an outlook on future research.
\end{abstract}

Keywords: crisis, cycle, finance, housing, policy

\section{Introduction}

Housing satisfies the need of humans for shelter (Denton, 1990), can be a major wealth component and is an important sector of the economy (Note 1). Furthermore, housing plays a critical role in labor economics and the urbanization process. Rapid urbanization and limited resources can place a strain on housing. Inadequate housing and poverty are often linked. In addition, housing sector dynamics can affect the broader economy (Poterba \& Noguchi, 1994), and help explain cross-country differences in the macroeconomic performance (Muellbauer, 1992). Favorable finance conditions tend to promote investment and economic growth (e.g., Keynes, 1936; Levine, 2005), and unfavorable ones can do the opposite. For example, real estate market corrections run through the account of events preceding crises such as in the United States in the 1930s and late in the first decade of the 2000s, in Iceland late in the first decade of the 2000s and in Scandinavian countries in the early 1990s (Claessens \& Kose, 2014). The housing market and the economy are intertwined through real, legal, regulatory and financial circuits (Mishkin, 2007). They are linked through the wealth effect (e.g., Keynes, 1936; Modigliani \& Brumberg, 1954; Friedman, 1957; Blanchard, 1985; Deaton, 1992) and the financial accelerator (e.g., Bernanke \& Gertler, 1989, 1995; Bernanke et al., 1996).

Understanding these circuits is critical in determining how housing market shocks influence economic activity, societal progress and wellbeing (e.g., Mishkin, 1978; Claessens \& Kose, 2014). To anticipate the implications of these shocks and to take appropriate action, policy makers need to identify the source and nature of shocks. Interesting questions are whether housing market outcomes are a source of a shock or a reflection of economic development. Another question is whether housing-related policies impact not only the housing sector, but also the wider economy. Knowledge about the implications of housing-related policy on the broader economy is imperfect. This means that a better understanding of the functioning of the housing market is necessary. Interventions in the housing market can profoundly affect the dynamics in this market, economic activity, societal progress and wellbeing (ECB, 2003). Therefore, care needs to be taken when designing or revising housing-related policies (OECD, 2011). Questions worth exploring are whether these policies address causes or 
symptoms; whether they help to reach economic, financial, social and environmental objectives; as well as whether they have unintended consequences.

Housing supply, housing demand and the institutional framework in the housing sector typically vary across countries. These disparities can influence the transmission of policy measures to the economy (Muellbauer \& Murphy, 1997). Variations in political, economic, financial, regulatory and environmental conditions tend to give rise to different policy tasks. Policy makers intervene in the housing market in the pursuit of economic, financial, social and environmental objectives. Strategic priorities, reform payoffs and the relative importance of policy instruments change with the position of an economy along the development path (e.g., Poterba \& Noguchi, 1994; Dabla-Norris et al., 2016). Worldbank (1993) summarizes the key areas of a potential housing policy reform depending on the level of development of an economy. Policy makers should consider market forces as well as the desires and prospects of the various housing market stakeholders. They ought to strive for a balance between the costs and the benefits of the different policy tools. The housing-related policy toolbox is comprehensive and under ongoing review and revision (e.g., Andrews et al., 2011).

Policies can have a bearing on housing supply, housing demand, the institutional framework in the housing sector and sectoral management. Furthermore, they can be aimed at influencing economic indicators, addressing market imperfection and combating market failure (e.g., Igan et al., 2014). When designing policies aimed at the housing sector (or the broader economy), the policies' effects on the broader economic (or the housing sector) performance should be considered. A housing market that is responsive to the needs of its market stakeholders may be conducive to greater macroeconomic resilience to shocks (e.g., Caprio \& Honohan, 2001; OECD, 2011; Claessens \& Kose, 2014). An enabling strategy for housing is likely to include the promotion of property rights, collateral security, housing-related infrastructure and housing finance as well as a viable subsidy system and an appropriate institutional framework. Growing urbanization, amongst other factors, can put pressure on policy makers, who have limited resources and are in charge of adequate housing, housing-related infrastructure and environmental quality, to choose among competing objectives (Worldbank, 1993). In slums and squatter settlements, for example, there are conflicts between the availability of affordable, equitable housing and the feasibility of environmental and health standards.

Housing-related policies may affect the broader economy by altering spending decisions as well as finance and labor market outcomes. Policies have limits. For example, the room for fiscal maneuver is limited, bearing in mind the path for output, government expenditure and public debt. Central banks are constrained by the zero lower bound on nominal interest rates (e.g., Eggertsson \& Krugman, 2012; Igan et al., 2014). Prolonged expansionary monetary policy poses challenges for policy makers, the public and private sectors, and is apt to increase the risk of financial and macroeconomic instability (Bean et al., 2015). Policies that significantly redistribute resources in a given society typically create social friction and can be politically infeasible (Alpanda \& Zubairy, 2016). Policies directed at one segment, i.e., rural or urban housing, formal or informal housing, lower- or higher-income housing, regulated or unregulated housing market participants, may not encroach upon other segments. However, dynamics in one segment may be linked to others. Policies aimed at leveling the playing field for different segments are not a subject of this study.

It is difficult to evaluate the effects of policy differences on the performance of the housing sector, which can be reflected in house prices as well as the quantity and quality of housing units, and to understand this sector's contribution to the broader economic performance without reliable, accurate, timely and easy to understand data. The currently available housing market information does not always meet these requirements. With these caveats in mind, this study explores the literature on housing-related policies. The objectives are to investigate the interplay between the housing market and the wider economy and to contribute to the debate regarding how to best optimize the housing-related policy toolbox. Policy reform success can depend on political, economic, financial, regulatory and institutional frameworks (ECB, 2003). Reform success, timing and sequencing are not topics of this study, but would be worthwhile to examine. This study focuses on the impact of macroeconomic and prudential policies on housing market outcomes. Highlighted are predominantly the effects of individual tools rather than their interaction. Although it would be worthwhile, this study does not compare institutional frameworks and policy toolbox compositions across countries and over time.

This study may be relevant for an audience interested in housing-related policies. It opens with the key findings in the literature on the interplay between the housing market and the wider economy. Section 2 explains the rationale for housing market regulation. Then, by summarizing the research results in the literature, potential implications of housing market corrections on financial and macroeconomic stability are stressed. Section 3 deals with the effects of housing-related policies by drawing on the important findings in the literature. The study concludes with a brief discussion as well as an outlook on future research. 


\section{The Housing Market and the Wider Economy}

\subsection{Reasons for Regulating the Housing Market}

Figure 1 shows a housing market model. Market forces tend to influence housing market outcomes, which can have repercussions for societal progress and wellbeing. The wealth effect and the financial accelerator are two aspects that connect the housing market and the broader economy. Bernanke et al. (1996) define the financial accelerator as an amplification of a shock to the economy brought about by finance condition changes. Housing market moves can affect private sector spending by more than the conventional wealth effect if the financial accelerator works (e.g., Bernanke \& Gertler, 1989, 1995; Bernanke et al., 1996). To the extent that these fluctuations have an impact on the creditworthiness and spending capacity of the private sector, this can exacerbate the economic implications of shocks. For example, negative shocks affecting the private sector's financial position can be associated with spending drops, which can deepen and prolong economic contraction as well as weaken and lengthen recoveries (e.g., Kiyotaki \& Moore, 1997; Aoki et al., 2004; Iacoviello, 2005; Almeida et al., 2006; Igan et al., 2014). Real estate market corrections may also affect borrowers facing higher agency costs in the credit market more than those facing a lower external finance premium. Credit reallocations from lower to higher net worth borrowers after the occurrence of a shock may put lower net worth borrowers under extra financial pressure (Bernanke et al., 1996).

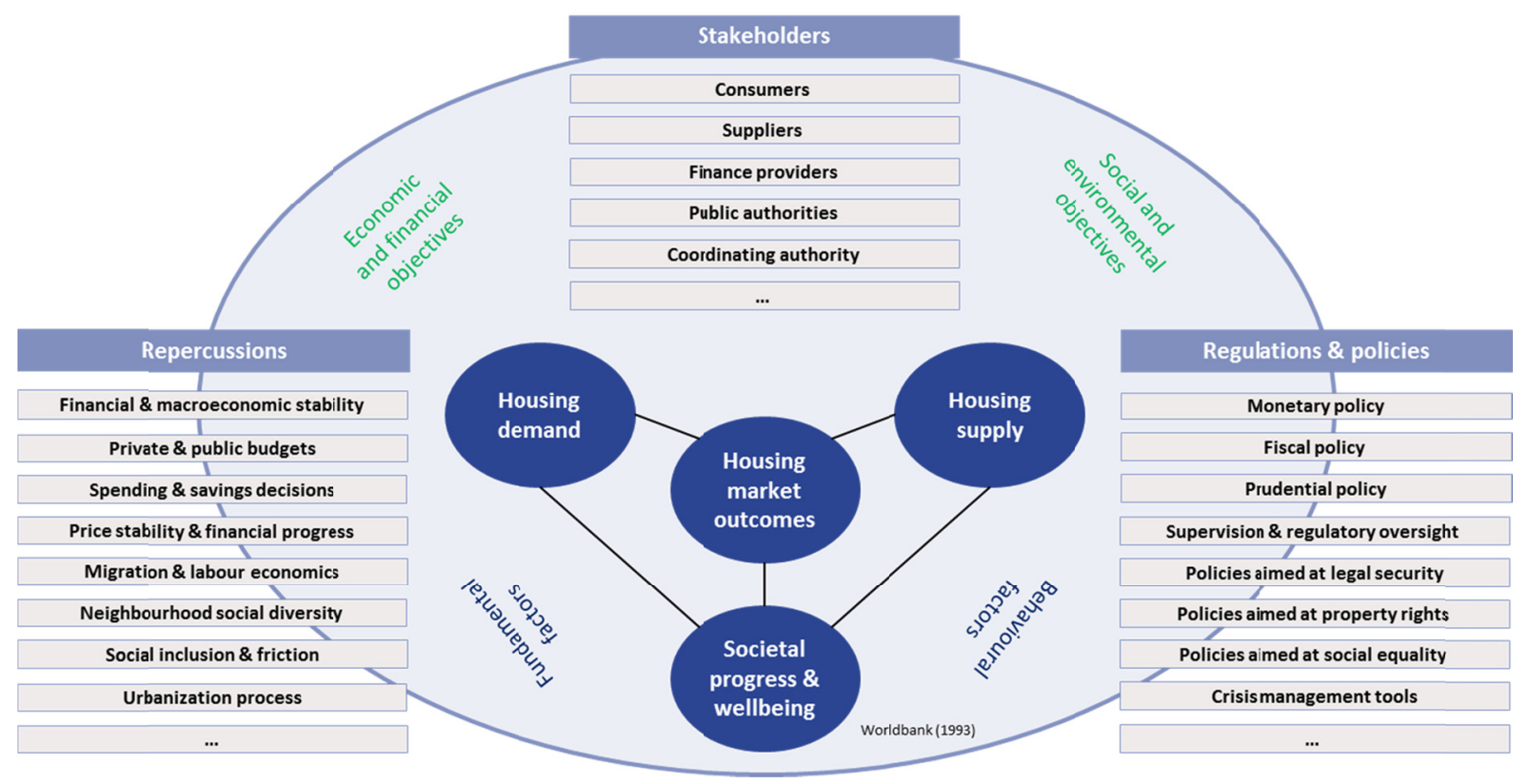

Figure 1. Housing market model

The marginal propensity to consume out of wealth tends to decrease with increasing wealth (Carroll \& Kimball, 1996). Lower net worth households tend to have a higher marginal propensity to consume out of wealth (King, 1994). Lower income households tend to allocate a larger portion of income to housing, and the average portion of household income allocated to housing grows with the level of economic development (Worldbank, 1993). Wealth distribution in a society tends to matter for the aggregate consumption behavior (e.g., Davey, 2001; ECB, 2003). Buiter (2010) argues that, in a closed economy with representative agents, aggregate consumption can be affected by wealth redistribution among agents with different marginal propensities to consume out of wealth. The effect of a housing market correction on aggregate consumption may be greater in economies where the fraction of lower net worth households is larger (Mian et al., 2013). The prospect of private sector spending deterioration can be one reason for policy action (Eggertsson \& Krugman, 2012). In addition, the magnitude and distribution of wealth changes in a given economy tend to have implications for the effectiveness and the design of macroeconomic policy (Mian et al., 2013).

Housing investment typically requires financing, which allows consumers to better allocate resources over time. Finance matters for economic growth (e.g., Levine, 1999, 2005), and policies can shape the finance system. Taken together, policy and growth are linked (La Porta et al., 1998). Housing-related policies can affect spending and saving patterns. Financial depth and breadth tend to evolve with the level of development of an economy. 
Housing loans tend to become marketable once property rights, tenure security, collateral security and foreclosure are in place to safeguard borrowers' and lenders' interests. Housing finance can be a major line of business for lenders. However, housing finance products are inaccessible for many consumers in lower income economies, and housing underinvestment exists (Worldbank, 1993). High margins between primary and secondary housing finance market products can be a result of market inefficiencies such as inadequate policies and finance products. The housing finance system can be supplemented by approaches to ease credit, collateral and market risks via legal security, collateral appraisals, borrower assessments and insurance products. Drudi et al. (2009) stress that financial liberalization and housing market outcomes are associated.

ECB (2003) supposes that financial liberalization strengthens the housing wealth effect on consumption and intensifies house price sensitivity to monetary policy. Winkler (2016b) finds that the housing wealth effect tends to be larger in countries where access to credit is easier. Mian et al. (2013) show that households' propensity to consume out of housing wealth tends to grow with their indebtedness. Enabling housing equity withdrawals can promote household spending (Davey, 2001). Financial liberalization without adequate financial sector regulation and supervision can fuel instability, e.g., if credit standard relaxation and debt accumulation during booms are associated with nonperforming loan buildup during busts (OECD, 2011). Igan et al. (2014) show that financial distress of borrowers can spill over to lenders. This may necessitate policies targeted at financially overextended households or aimed at assisting households' access to credit by intervening in the financial sector through procedures for the recovery and resolution of lenders (Claessens et al., 2014). Policy responses to crises have to be designed carefully to enhance financial and macroeconomic stability, limit the loss borne by taxpayers, protect depositors and critical financial services, and minimize moral hazard and continuous excessive risk taking by borrowers and lenders (Igan et al., 2014).

Housing market outcomes tend to play a critical role in determining the persistence and amplitude of macroeconomic cycles (e.g., OECD, 2011; Claessens et al., 2012). If a bubble bursts, policy makers should moderate, rather than accelerate, housing market correction (Bean et al., 2015). Housing-related expenditure changes furthermore affect price stability. For example, this is because housing-related expenses account for 22.3 percent of the basket of the euro area harmonized index of consumer prices, and represent 42.2 percent of the consumption basket constituting the United States consumer price index. Central banks seek to ensure price stability because it tends to promote sustainable macroeconomic growth (Kuttner \& Shim, 2012). Housing market outcomes in terms of quality, quantity and price also tend to have an impact on neighborhood social diversity and social inclusion, which can in turn influence economic performance (e.g., Galster, 2007; Andrews et al., 2011). Moreover, relative housing market conditions can have implications for migration and labor economics (e.g., Cameron \& Muellbauer, 1998; Cannari et al., 2000; Saks, 2008). In addition, housing underinvestment is associated with a shortage of affordable formal housing, increased commuting as well as depressed residential and labor mobility (Worldbank, 1993).

Furthermore, the tenure of housing and housing supply flexibility tend to matter for social inclusion as well as residential and labor mobility (e.g., Saks, 2008; Andrews \& Caldera Sanchez, 2011). Common forms of housing tenure are owning and renting. The relative share of owner-occupied housing and rental housing in the housing stock is influenced by demographics; by psychological, sociological and economic factors; and by finance conditions and policies. In this context, one must stress that unsubsidized tenants tend to be the most flexible movers (e.g., Hughes \& McCormick, 1981; OECD, 2011). Residential mobility can increase labor market efficiency (Andrews \& Caldera Sanchez, 2011). Residential mobility tends to be lower in an environment where housing market frictions are higher (Rupert \& Wasmer, 2012) and access to credit is tighter (Andrews \& Caldera Sanchez, 2011). In addition, negative housing equity tends to reduce residential mobility (Ferreira et al., 2012), and housing supply flexibility is associated with superior labor market outcomes (e.g., Glaeser \& Gyourko, 2002; Andrews, 2010; Meen, 2011).

To summarize, there are numerous reasons why housing market regulation is desirable. For example, this is because housing market dynamics can influence, amongst other factors, private and public budgets, spending and saving decisions, inflation, financial progress and labor economics. Prevention is better than cure, and if adverse housing market outcomes are foreseeable, it is often better to address rather than ignore those challenges. To develop a normative view of the housing market, Worldbank (1993) advises to consider the needs and prospects of the various housing market stakeholders, which includes consumers, suppliers, finance providers as well as public authorities. To improve the functioning of the housing market, policy makers should reconcile the mutually incompatible interests of the diverse market stakeholders; they should also assess housing sector reform effects on the sectoral and broader economic performance. 


\subsection{Housing Market Corrections and Financial Crises}

Financial crises have common patterns (e.g., Reinhart \& Rogoff, 2009; Claessens et al., 2014), and housing market corrections frequently appear in the accounts of events preceding crises. Housing market boom and bust cycles are sequences of expansion and contraction. Detecting whether housing is overvalued, undervalued or fair-valued is more an art than a science. Expecting policy makers to predict housing market cycle peaks and troughs and to take instantly the respective countercyclical actions is unrealistic. Claessens \& Kose (2014) show that the classification of cycle stages in the literature is inconsistent. They emphasize that asset price booms and busts can happen in an environment with or without distortion, uncertainty and rational market participants. Igan et al. (2014) stress that the relations between housing prices, rents and income may be indicators of whether housing is fairly valued, but highlight the importance of information concerning housing demand momentum and supply conditions. The housing market is imperfect. For example, housing is a heterogeneous good, the housing market is not frictionless and there often is insufficient competition in this market. Market forces shape housing market outcomes (Figure 1), and housing prices, quantity, quality and affordability are related (Worldbank, 1993).

The housing supply and demand curves tend to be affected by fundamental and behavioral factors and policies. Andrews et al. (2011) argue that, contingent on the nature of housing supply and demand, there can be price and quantity distortions in the housing market. Imbalances in this market might put financial and macroeconomic stability at risk. There are attempts to predict real estate prices, but the market forces alone cannot fully explain the price developments (e.g., Kasparova \& White, 2001; Girouard et al., 2006; Ortalo-Magne \& Rady, 2006; Andrews, 2010; Grimes \& Aitken, 2010; Hiebert \& Sydow, 2011; Kuttner \& Shim, 2012). ECB (2003) stresses the local character of housing market dynamics. Factors that help account for different real estate price changes include wealth developments as well as demographic, economic, financial, regulatory, political, institutional and technological aspects. Psychological and sociological factors can amplify the response of the housing market to a shock. The functioning of the finance system can also influence how the housing market responds to a shock (e.g., Muellbauer, 1992; Maclennan et al., 1998; Kasparova \& White, 2001). Housing wealth and loan growth can move in tandem, masking the increasing exposure of households to a housing market correction.

Housing finance evolution and oversight are critical elements of an enabling strategy for housing. Property rights encourage housing transactions by safeguarding transaction partners' interests, and are thus prerequisites for developing housing finance. Claessens \& Kose (2014) argue that credit growth can be associated with productivity, capital flow and policy changes. Factors underlying consumer debt accumulation can include optimism about wealth prospects and easier access to credit due to financial innovation and deregulation (e.g., ECB, 2003; Andrews et al., 2011; Igan et al., 2014). Financial innovation may take the form of investment, finance and insurance products, while financial deregulation is likely to include changes in the finance system to foster competition, the removal of market frictions to improve efficiency, or the easing or abolishment of product restrictions. The cost and availability of credit tends to be linked to borrower balance sheet and cash flow dynamics (OECD, 2011). As an asset, housing can serve as a credit collateral. The outstanding balance on a housing loan can be related to the housing value. Asset price movements can thus have an impact not only on the value of an asset serving as a credit collateral, but also on the net worth, creditworthiness, access to credit and spending of consumers (e.g., Kiyotaki \& Moore, 1997; Hofmann, 2001; Mian et al., 2013).

Credit-financed housing investment can inflate house prices (Reinhart \& Rogoff, 2009). It is difficult to identify whether asset price developments and collateralized borrowing growth are on a sustainable path, or whether the dynamic interactions between asset wealth and collateralized borrowing drive the progression in asset prices and the credit market. Real estate loan growth accompanied by real estate price booms can mask the growing exposure of the private sector to a real estate market correction, which may trigger financial instability and even financial crises (Schularick \& Taylor, 2012). For example, financial distress from unsustainable household indebtedness can stem from a reversal of an upward trend in the consumer debt market, from asset price corrections, from domestic currency depreciation against the foreign currency and the prevalence of foreign-currency loans, or from consumer price index (CPI) inflation and the prevalence of inflation-indexed loans. Household financial distress arising from a mounting debt burden can spill over to individual finance providers and the financial sector.

Finance providers cannot perform financial intermediation for the benefit of the economy with dysfunctional finance markets. Credit and market risks, amongst other factors, hamper the functioning of the finance system. Financial development tends to start with short-term finance, as long-term finance is riskier. Financial liberalization may allow for financial development based on innovative finance solutions, which are unlikely to be a panacea in risk-prone countries. Forces such as exchange rate risk, price risk and finance condition changes 
may impair finance market participants' financial positions and can threaten financial development and stability (e.g., Mishkin, 1978; ECB, 2003; Reinhart \& Rogoff, 2009). Economic contraction and rising unemployment may follow from worsening creditworthiness and decreasing spending capacity in the private sector (e.g., Eggertsson \& Krugman, 2012; Laeven \& Laryea, 2014). High household indebtedness and negative housing equity can be a drag on labor economics (e.g., OECD, 2011; Ferreira et al., 2012). Housing market corrections and the associated adverse effects on the financial position of borrowers can give rise to inefficiencies such as insufficient spending on housing improvement and maintenance (Igan et al., 2014).

In the run-up to financial crises, financially overextended borrowers may face borrowing and debt servicing constraints, and nonperforming loans are likely to accumulate on the balance sheet of lenders. Lenders might put additional pressure on lower net worth borrowers by tightening lending standards and credit availability. Foreclosures can further depress house prices as well as reduce borrowers' net worth, access to credit and spending (e.g., Shleifer \& Vishny, 1992; Mian et al., 2015). The neglect and decay of vacant properties can have negative neighborhood externalities. Borrowers' financial distress can spill over to the lenders. Lenders may reevaluate asset prices, collateral values and credit risk exposures. Insufficiently capitalized lenders may be unable to absorb the losses associated with the revaluation of assets. Inadequately capitalized lenders can experience distrust by investors, capital withdrawals and financing constraints and therefore might be unwilling to renegotiate loans or engage in investment activities (e.g., Shleifer \& Vishny, 2011). These incidents might be indicators of a credit crunch.

\subsection{Financial Crises and Economic Outcomes}

Not every credit boom ends in a financial crisis, but the risk grows with a boom's length and severity (Igan et al., 2014). One in three credit booms tends to be followed by a crisis, and about half of the booms lasting more than six years are likely to end in a crisis (Claessens \& Kose, 2014). Mechanisms at work preceding a crisis include asset price inflation, credit expansion, marginal asset growth, rising leverage, lower lending standards, financial engineering, remuneration schemes distorting behavior, substantial capital flows, sustained current account deficits, lack of finance market transparency, growing opacity of risk exposures, increasing importance of unregulated players in the finance market, fragile finance models, thin capital buffers, systemic risk buildup as well as inadequate oversight and associated agency problems. Concurrent occurrence of these aspects can indicate growing financial instability. Financial crises can occur in more and less benign macroeconomic circumstances, in more and less financially integrated markets, in richer and poorer economies as well as on national, multinational and global scales. Crisis triggers are hard to identify but may include changes in the confidence of finance market participants, suspicion of asset overvaluation or overindebtedness, less benign wealth expectations of consumers as well as uncertainty about economic growth, finance conditions and policy change. Financial crises can originate from economic contraction, which can also follow from financial crises (Claessens et al., 2012).

When an economy contracts, national output and private sector expenditure tend to fall and public sector expenditure tends to rise. In comparison with economic contractions unassociated with crises, those associated with crises tend to be more pronounced and protracted. Studies show that banking crises tend to last longer and have more severe implications for the economy and public resources than other types of crises (e.g., Reinhart \& Rogoff, 2009; Laeven \& Valencia, 2013; Claessens \& Kose, 2014; Igan et al., 2014). Regardless of the approach, the estimated financial crisis effects tend to vary. Claessens \& Kose (2014) argue that some variation is explained by ambiguity regarding the dating and classification of financial crises. They stress that, in emerging markets, the decline in consumption in an environment of crisis-induced economic contraction can be up to ten times larger than declines unassociated with crises. Output loss associated with banking crises, measured as the accumulated deviation from trend GDP, is, on average, about 20 percent of GDP during the first four years including the crisis start year (Laeven \& Valencia, 2013). Abiad et al. (2014) report that seven years after a crisis start year the median output loss measured as the GDP trend deviation is, on average, 10 percentage points.

Economic recoveries associated with financial crises can be weaker and slower than those unassociated with a crisis. Compared to episodes unassociated with crises, cumulative GDP growth tends to be up to 2.5 percentage points lower in the four quarters after a crisis-induced economic trough (Kannan et al., 2014). Crises tend to weigh on public resources as a result of increased public spending on automatic stabilizers, discretionary public deficit growth, expansionary fiscal policies and falling government revenues. Laeven \& Valencia (2013) estimate the fiscal costs net of recovery proceeds relative to GDP during the first six years from the crisis start year, and identify average net fiscal costs associated with financial crises of 13.3 percent of GDP. They discover that the average recovery rate is only 18.2 percent of the gross fiscal costs. Public debt tends to grow by 86 percent, on average, in the three years after the onset of a banking crisis (Reinhart \& Rogoff, 2009), and the median public 
debt growth tends to be 12.1 percent of GDP in the same period (Laeven \& Valencia, 2013). Coenen et al. (2012) suggest that a public stimulus equal to one percent of baseline, pre-stimulus GDP for two years can raise GDP by 1.3 percent in the United States and 1.1 percent in Europe.

Leverage can be a reason for slow growth in the wake of crises (Bean et al., 2015). Mian et al. (2013) and Igan et al. (2014) reveal that household consumption tends to decline more in an environment where house prices fall and household indebtedness is high. Igan et al. (2014) also find that household deleveraging tends to be more intense during house price correction preceded by amplified debt accumulation. Deleveraging of indebted households helps explain stronger economic contraction in an environment where house prices fall (Igan et al., 2014). Claessens et al. (2012) claim that economic contraction accompanied by house price correction is, on average, deeper and takes about 1.5 quarters longer than when unaccompanied by such correction. They show that economic recoveries coinciding with house price booms are, on average, stronger and are about two quarters faster than those unaccompanied by house price booms. Abiad et al. (2011) argue that economic recoveries unaccompanied by credit booms, i.e., creditless recoveries, are more common after the occurrence of banking crises preceded by credit booms. They suggest that one of five recoveries is creditless. Claessens et al. (2012) find that output growth during recoveries accompanied by asset price and credit booms is, on average, up to four percentage points higher than output growth during recoveries unaccompanied by such booms.

\section{Housing-related Policies and Societal Outcomes}

The functioning of the finance market is one of the important elements in an enabling strategy for housing. Such a strategy allows for affordable housing for consumers from different ethnic groups and helps achieve economic, financial, social and environmental objectives. Critical questions in this respect are which policies are available, and when they should be used to bring about a dysfunctional housing market to work. Housing sector reforms that ignore the broader economic conditions are likely to have limited impact on societal progress and wellbeing. The positive and negative implications of housing-related policies for housing market outcomes need to be skillfully balanced. The timing and mutual interactions of policy measures need to be carefully coordinated and are critical for the success of the applied policy set. For example, signaling that expansionary policies are the preferred response to crises can raise risk to financial stability by encouraging moral hazard (e.g., Farhi \& Tirole, 2012; Claessens \& Kose, 2014; Bean et al., 2015).

Policies have limits. For example, in a low interest rate environment, the implications of sustained expansionary monetary policy on aggregate demand is likely to be limited, especially if inflation is below target and central banks are unable to cut the policy rate to a level lower than the natural interest rate. In addition, prolonged relaxed monetary policy can threaten financial stability by boosting credit-financed riskier investment and inflating asset prices. If the policy rate reaches the zero lower bound and central banks already turn to unconventional instruments, structural measures may be needed to safeguard the economic progress, and the burden on fiscal policy actions tends to grow to provide the impulse for sustained aggregate demand. Public sector stimulus can counterbalance temporary weakness in private sector demand.

Continuous deterioration in private sector spending may be offset by a corresponding increase in deficit spending to maintain a constant aggregate demand level and to support employment. Deficit spending enlarges the public debt burden. The scope for fiscal maneuver tends to narrow as public debt grows. Public debt dynamics can worsen if doubts arise over the creditworthiness of the sovereign. Fiscal consolidation and inflationary monetary policy tend to help the government to manage the public debt burden. In addition, countercyclical prudential policies can help mitigate risk to financial stability by ensuring the financial system's resilience to shocks, safeguarding the soundness of lenders, discouraging excessive credit accumulation and inhibiting risky investment. However, individual policy measures are not a panacea. I next elaborate on the effects of different housing-related policies by drawing on the key findings in the existing literature.

\subsection{Monetary Policy and Housing Market Outcomes}

The question is whether monetary policy is efficacious at regulating housing market outcomes (Figure 1). Monetary policy consists of actions by central banks, which often seek to ensure price stability in the pursuit of macroeconomic objectives. There are conventional and unconventional monetary policy measures. Central bank decisions can manipulate money supply and costs, aggregate supply and demand, and affect the trade balance and price stability through different channels (e.g., Bernanke \& Gertler, 1995; Mishkin, 2007). Figure 2 illustrates the key transmission channels (ECB, 2016). Tighter monetary policy may lower the likelihood and extent of macroeconomic disruption associated with financial market volatility, but tends to hamper aggregate demand (Bean et al., 2015). Although housing market outcomes can put financial stability at risk, there is a relatively heated debate about whether central banks should target real estate prices. Central banks pay close 
attention to asset prices to the extent those contain price stability information. However, they typically refrain from targeting asset prices, as this is tantamount to fixing asset prices and can imply misallocation and dislocation. Targeting asset prices would furthermore require reliable, accurate, timely and easy to understand indexes, and existing indexes often do not meet these requirements.

Housing plays a key role in how the economy responds to monetary policy (Bernanke \& Gertler, 1995), but one policy action can differently affect the heterogeneous housing markets in a single monetary regime (Kasparova $\&$ White, 2001). For example, variations in the functioning of the housing finance market imply heterogeneity in the monetary policy transmission mechanism. Depending on this mechanism, monetary policy actions may be predominantly directed at finance market participants, segments or products. Modigliani (1971) highlights that the wealth effect is crucial in the response of the economy to monetary policy. Factors such as legal security, credit contract design and consumer indebtedness matter for consumer spending behavior and thus the transmission of monetary policy to the economy (Calza et al., 2013). To the extent that monetary policy signals have an impact on consumers' creditworthiness, credit conditions and spending, the macroeconomic implications of the initial signal can be amplified (e.g., Iacoviello, 2005; Claessens et al., 2012). The importance of the financial accelerator varies across monetary regimes and may depend on the position of an economy along the development path (e.g., Bernanke \& Gertler, 1989, 1995; Bernanke et al., 1996).
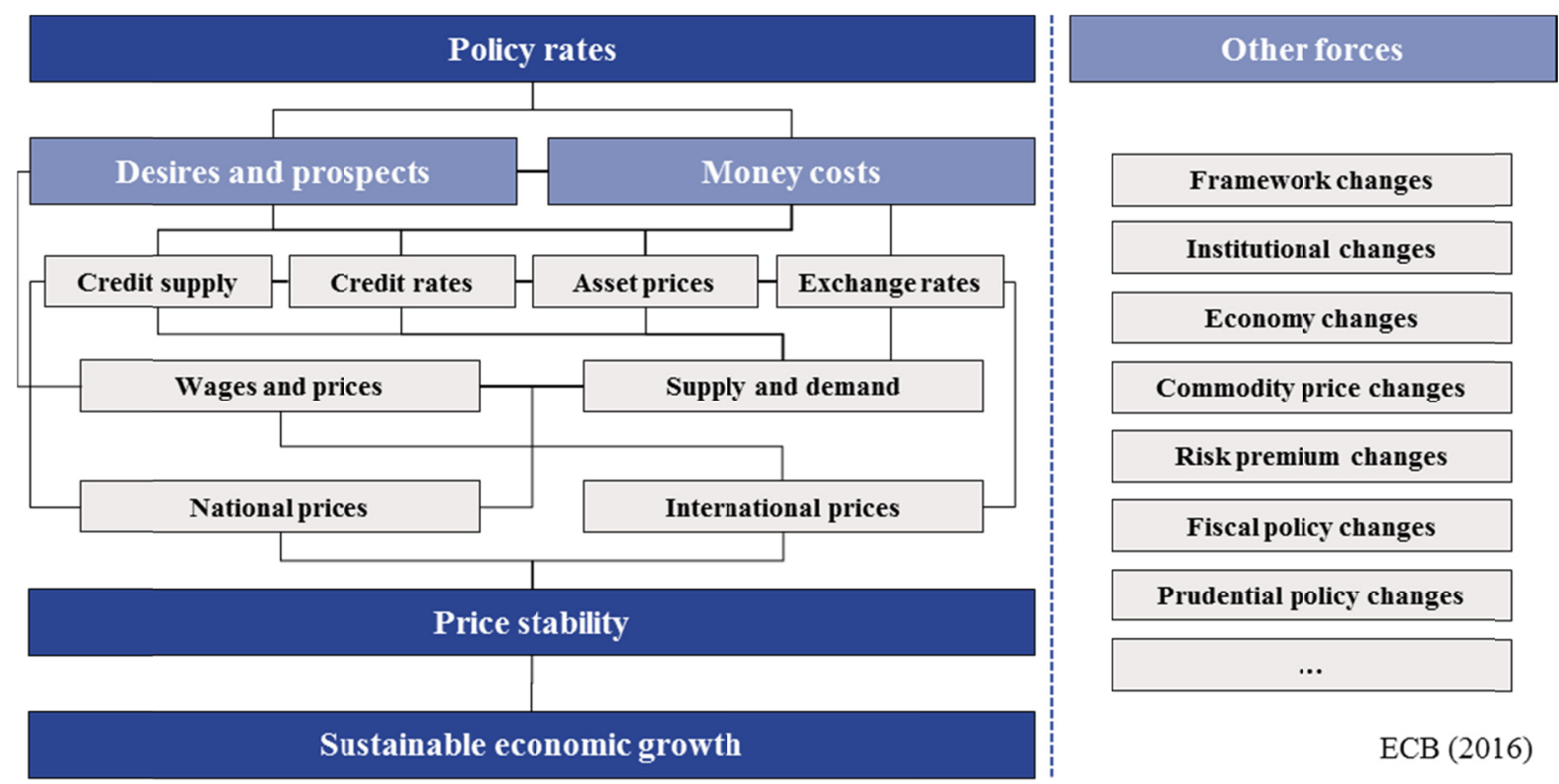

Figure 2. Monetary policy transmission mechanism model

Macroeconomic policies influencing growth and national income can affect the housing market performance (Worldbank, 1993). Kuttner \& Shim (2012) propose that monetary policy, with the exception of interest-rate policy, is ineffective in controlling housing market outcomes. Maclennan et al. (1998) argue that the response of the economy to policy rate changes is lower in countries where rental housing is important, housing finance is less developed and housing transaction costs are higher. Kiyotaki \& Moore (1997) stress that interest-rate policy affects the financial accelerator. Interest rate increases can put loan servicing to the test. Compared with economies where fixed-rate loans dominate, policy rate changes tend to be passed on to consumers more quickly in economies where variable-rate loans prevail (e.g., ECB, 2003; Igan et al., 2014). Borrowers facing higher agency costs in the credit market tend to bear the brunt of a shock to the finance system, as access to credit is more difficult for them than for borrowers facing a lower external finance premium (Bernanke \& Gertler, 1995). In addition, loans granted by low-capital lenders tend to be more policy rate sensitive than loans granted by high-capital lenders (Kishan \& Opiela, 2006).

Kuttner \& Shim (2012) review the literature on the implications of policy rate changes for real estate prices. They find that a one percentage point interest rate increase tends to slow house price growth by between 1.2 and 6.4 percent. Ahearne et al. (2005) find that expansionary monetary policy tends to precede housing market booms. They suggest that the policy rate tends to bottom out about three years before real estate prices peak. 
Monetary policy alone is likely to be a blunt tool for dealing with house price dislocation and housing credit accumulation. Shi et al. (2014) argue that prudential policy may be better suited than monetary policy to influence housing market outcomes, especially in economies where policy rate changes are constrained by macroeconomic aspects. Kuttner \& Shim (2012) indicate that policy rate increases together with prudential policy tightening negatively affect house prices. Igan et al. (2014) stress that expansionary monetary policy can help forestall economic contraction during episodes of consumer deleveraging. Claessens et al. (2014) emphasize that such policy stimulates aggregate demand and the economy, assists debt servicing and therefore supports the asset side of lenders' balance sheet, but tends to fuel asset prices, credit-financed riskier investment strategies and financial instability.

\subsection{Housing-related Fiscal Policy and Societal Outcomes}

Fiscal policy can manipulate housing market outcomes by biasing consumer spending and finance decisions. Fiscal policy is discretionary or non-discretionary. Discretionary fiscal policy is the deliberate change of government revenue and expenditure to influence aggregate demand by redistributing resources. Housing-related revenue instruments include raising taxes on housing transactions as well as on housing investment income and capital gains. Examples are taxes on imputed rent from owner-occupied housing as well as real estate capital gains and transfer taxes. Housing-related expenditure instruments include subsidies, allowances and the provision of housing services by the government or government-sponsored entities. The impact of fiscal instruments on different types of households varies (Alpanda \& Zubairy, 2016). Worldbank (1993) advises policy makers to promote property rights, remove supply barriers, lower housing production costs and improve access to finance before using subsidies as a last-resort instrument to ensure the functioning of the housing market.

Fiscal measures can strain public resources. There are on-budget and off-budget subsidies (Worldbank, 1993). Alpanda \& Zubairy (2016) cite that the United States government has foregone about 68 billion dollars of 2012 revenue from the tax deductability of mortgage interest payments. The scale of housing-related expenditures relative to the public budget tends to differ across economies, as does the mix and effects of those measures. Alpanda \& Zubairy (2016) rank several housing-related fiscal instruments in terms of their efficacy in raising government revenue per unit of output loss; they find that reducing the tax deductability of mortgage interest payments is the most effective policy, followed by taxing imputed rents from owner-occupied housing, increasing property taxes and reducing depreciation allowances for rental housing. Fiscal policy can influence housing demand and supply as well as the choice between owning and renting (e.g., Rosen, 1979; ECB, 2003; Huefner \& Lundsgaard, 2007; Kuttner \& Shim, 2012). To ease policy-induced distortions, OECD (2011) and ECB (2003) recommend more harmonized fiscal treatment of owner-occupied and rental housing, new and existing housing as well as housing investment and other types of investment.

Property rights are a precondition to housing-related fiscal policy. The success of housing-related fiscal policy can depend on the portion of formal housing in the housing stock (Worldbank, 1993). Other studies suggest considering the sensitivity of housing supply when assessing the impact of housing-related fiscal policy on housing market outcomes (e.g., Swank et al., 2002; Hilber \& Turner, 2014). Preferential fiscal policy treatment of a specific housing tenure may influence labor market outcomes (e.g., Lundborg \& Skedinger, 1999; Haurin \& Gill, 2002; Alpanda \& Zubairy, 2016). Van Ommeren \& Van Leuvensteijn (2005) show that the levy of real estate transfer tax lowers the relocation probability of owner-occupiers. OECD (2011) suggests that portable housing allowances do not hinder residential mobility to the same extent as the direct provision of housing services by the government or government-sponsored entities. Noord (2003) claims that housing-related fiscal policy differences across the member states of the Economic and Monetary Union of the European Union should be a concern because they contribute to an asymmetric transmission of monetary policy to the single monetary regime countries.

Kuttner \& Shim (2012) show that the links between fiscal policy and the housing market cycle are inconclusive. This is in contrast to Claessens et al. (2014), who argue that an expansionary fiscal policy promotes aggregate demand and asset prices. Worldbank (1993) also highlights that preferential fiscal policy treatment can add to accelerated housing investment and house price growth (Worldbank, 1993). Andrews et al. (2011) warn that preferential fiscal treatment of credit-financed housing investment can be reflected in heightened house prices. Keen et al. (2010) propose that taxation-induced bias in favor of credit-financed housing investment can put financial stability at risk. Hilber \& Turner (2014) emphasize that the tax deductability of mortgage interest payments is capitalized into house prices rather than home ownership attainment, in particular in an environment where housing supply is inflexible. Noord (2003) highlights that the preferential fiscal treatment of housing investment income and capital gains is associated with elevated house price volatility. Poterba (1992) suggests 
that fiscal policy, which reduces the depreciation allowances for rental housing, is associated with rental housing investment declines and rent increases.

Worldbank (1993) emphasizes that housing-related subsidies should be well targeted, limited in time and house price neutral and furthermore should not dampen housing supply flexibility. With the prospect of government expenditure and public debt in mind, governments may increasingly be concerned about the respective costs and benefits of fiscal policy instruments under consideration, including those stimulating the housing market. The tax deductability of mortgage interest payments and the exclusion from taxable compensation of imputed rent from owner-occupied housing represent benefits to housing owners (Poterba \& Sinai, 2008). Hilber \& Turner (2014) stress that the tax deductability of mortgage interest payments is a relatively expensive subsidy and ineffective in promoting social inclusion. They also note, as does Hanson (2012), that this tax incentive tends to be unassociated with home ownership attainment in aggregate. Hilber \& Turner (2014) furthermore find that the tax deductability of mortgage interest payments helps explain home ownership attainment of higher income households in an environment where housing supply is flexible.

Other studies also conclude that the tax deductability of mortgage interest payments disproportionately supports home ownership attainment among higher income households (e.g., Glaeser \& Shapiro, 2003; Andrews \& Caldera Sanchez, 2011; Hilber \& Turner, 2014). Housing owners may over-consume housing services if mortgage interest payments are tax deductible and imputed rent from owner-occupied housing is not taxed (e.g., Gervais, 2002; Glaeser \& Shapiro, 2003; Hanson, 2012). Gervais (2002) suggests that welfare could be gained from abolishing the tax deductability of mortgage interest payments. Poterba \& Sinai (2008) emphasize that housing owners may only face a moderate tax increase if the tax deductability of mortgage interest payments is abolished. Although housing owners who are affected by the reform may not appreciate the change (e.g., Glaeser \& Shapiro, 2003; Poterba \& Sinai, 2008; Andrews \& Caldera Sanchez, 2011; Hilber \& Turner, 2014), the removal of the tax deductability of mortgage interest payments can be effective in generating government revenue per unit of output loss (Alpanda \& Zubairy, 2016).

\subsection{Prudential Policy and Economic Outcomes}

Policies aimed at protecting the financial position of borrowers can mitigate borrower credit risk as well as support sustainable financial development and housing market performance. Policies such as those aimed at reducing borrowers' interest burden at the expense of lenders are likely to impede financial development. Andrews et al. (2011) argue that financial liberalization facilitates credit-financed housing investment, but can be destabilizing without adequate prudential standards and supervision. Prudential standards and supervision as well as viable primary and secondary housing finance markets tend to be important for housing market outcomes. Countercyclical prudential policies can help mitigate risk to financial stability. Macroprudential policy is a framework of standards aimed at ensuring the financial system's resilience to shocks, discouraging excessive credit accumulation and inhibiting risky investment by applying countercyclical instruments. Microprudential policy is aimed at ensuring the soundness of individual institutions. Within the prudential policy framework, credit growth can be influenced by setting capital and liquidity requirements, leverage ratios, underwriting and credit standards as well as lending and exposure limits.

Credit availability and costs are typically linked to borrower creditworthiness, as measured by indicators such as the maximum loan-to-value (LTV) ratio and the debt-to-income (DTI) ratio (Bernanke \& Gertler, 1995). The maximum LTV ratio refers to a minimum down payment requirement. The maximum DTI ratio limits a borrower's debt servicing payment to a fixed multiple of the income. Technological progress allows for innovative data-driven underwriting algorithms that can be used in addition to the lenders' conventional processes to assess borrower creditworthiness. In accordance with the prudential policy framework, lenders need to comply with capital requirements and consider risk weights on credit risk exposures such as claims secured on housing. By laying down preferential prudential policies, policy makers can incentivize lenders to engage in certain activities more than others and to prefer one funding instrument over another, i.e. there can be prudential policy driven distortion in primary and secondary housing finance markets.

Prudential standards, financing transactions and economic activity tend to be linked (Lown \& Morgan, 2006). Prudential policies help attenuate unsustainable finance market trends (Farhi \& Tirole, 2012), but may hamper credit-financed economic growth. These interrelations can have an impact on housing market outcomes, societal progress and wellbeing. For example, enabling housing equity withdrawals can promote indebted consumer spending by leveraging consumers' financial position (Davey, 2001). Residential mobility tends to be lower in an environment where down payment requirements are higher (Andrews \& Caldera Sanchez, 2011). Reductions in the maximum LTV and DTI ratios presumably curb social inclusion and finance market growth because resource-constrained consumers are less likely to be able to comply with the tightened minimum credit 
requirements (OECD, 2011). Lower maximum LTV and DTI ratios, together with higher provisioning requirements on housing loans, tend to slow the growth of housing loans and house prices (Kuttner \& Shim, 2012).

Increasing risk weights and capital requirements may be less efficacious at moderating credit growth if adequately capitalized lenders internalize policy induced capital cost increases. Prudential policies aimed at controlling housing credit supply to domestic investors may be ineffective in curbing house price growth associated with modest housing supply flexibility and excessive housing demand from foreign investors. To mitigate borrower credit risk, Collyns \& Senhadji (2002) advise lenders to look at borrowers' overall debt servicing capacity, in particular in environments where housing wealth and loans develop in tandem. Igan et al. (2014) observe that borrowers with inflation-indexed foreign-currency loans struggle with loan servicing more than borrowers with loans without such characteristics when inflation rises, the domestic currency depreciates against the foreign currency and disposable income stagnates. They argue that countercyclical prudential policies and to a lesser extent macroeconomic policies are useful for containing the implications of negative shocks on the ability of borrowers to meet debt payments.

Effective banking supervision can help limit the probability and impact of financial institution failure. There are national banking supervision as well as resolution and recovery systems. Banking supervision uses on-site and off-site examinations to monitor the prudency of financial institution management. Banking supervision can impose enforcement measures and involves the determination of whether a financial institution is failing or likely to fail. Financial services are increasingly global and integrated, and housing markets tend to be affected by international, national, regional and local realities. Further improvements and greater international cooperation may be needed to strengthen the regulatory framework for the oversight, resolution and recovery of lenders with cross-border operations. For example, OECD (2011) calls for an effective system of cross-border banking supervision and argues that international coordination has to improve.

Macroeconomic conditions, the financial framework as well as finance trends are in flux and give rise to complex and continuously changing banking oversight tasks. OECD (2011) stresses that appropriate financial sector regulation and supervision can balance the advantages and disadvantages of financial liberalization. Barth et al. (2012) call for more nuanced and effective regulation strategies and a carefully balanced mix of finance market discipline, banking supervision and government intervention. OECD (2011) claims that an effective oversight of the housing finance framework can promote macroeconomic stability. Employing the banking supervision index established by Abiad et al. (2010), Andrews (2010) stresses that effective banking supervision tends to lower house price volatility and has the potential to reduce house price volatility more than other factors, such as higher housing supply flexibility, elevated housing-related transaction costs and less generous tax deductability of mortgage interest payments.

\subsection{Housing Tenure and Societal Implications}

Housing tenure and housing market outcomes are related. Resource-constrained consumers must settle for inferior housing in terms of size, quality and tenure security if superior housing is unaffordable. Promoting legal security and housing-related infrastructure, for example, in informal settlements, is important for an enabling strategy for housing (Worldbank, 1993); but the transition from informal to formal housing can give rise to social friction unless gentrification is avoided. Housing market outcomes can be manipulated by policies aimed at safeguarding tenure security and shaping the housing tenure profile. Other forces that tend to affect the housing tenure profile include housing affordability, finance conditions and the relative performance of owner-occupied and rental housing (e.g., ECB, 2003; Alpanda \& Zubairy, 2016). Demand and supply mismatches in the owner-occupied and rental housing markets may be reflected in the price-to-rent ratio as well as in the price-to-income ratio relative to the rent-to-income ratio.

Housing tenure, neighborhood stability and labor market outcomes are interrelated (e.g., Cannari et al., 2000; ECB, 2003; OECD, 2011). Andrews et al. (2011) stress that unsubsidized tenants tend to be, on average, 13 percent (nine percent) more likely to relocate than owner occupiers without (with) credit. They also suggest that unsubsidized tenants are, on average, six percent more likely to relocate than subsidized tenants. Barcelo (2006) finds that subsidized tenants' mobility is higher than owner occupiers' mobility; interestingly, Hughes \& McCormick (1981) find the opposite. Housing transaction costs can reduce residential mobility (Haurin \& Gill, 2002), and may create lock-in effects (Lundborg \& Skedinger, 1999). Owner occupiers' moving costs are often higher and therefore their mobility tends to be lower than unsubsidized tenants' mobility (e.g., Van Ommeren \& Van Leuvensteijn, 2005; Coulson \& Fisher, 2009). Residential mobility tends to fall with age (Andrews et al., 2011). 
To stimulate labor market outcomes by fostering residential mobility, Barcelo (2006) advocates the promotion of unsubsidized rental housing, and Cameron \& Muellbauer (1998) recommend the reduction of housing-related transaction costs. Owner occupiers' relatively limited residential mobility can be associated with neighborhood stability (Coulson \& Fisher, 2009) and neighborhood social capital investment (DiPasquale \& Glaeser, 1999). Flatau et al. (2003) claim that higher home ownership rates tend to be associated with superior labor market outcomes, but others (e.g., Oswald, 1996; Munch et al., 2006; Coulson \& Fisher, 2009) challenge this finding. Household indebtedness (Flatau et al., 2003) and employer behavior (Coulson \& Fisher, 2009) can play a crucial role in the relations between housing tenure and employment. Indebted owner-occupiers tend to leave unemployment with higher probability (Barcelo, 2006). Andrews \& Caldera Sanchez (2011) stress that improved credit conditions tend to contribute to labor mobility. Ferreira et al. (2012) highlight that negative housing equity is likely to reduce labor mobility.

Lower net worth and younger consumers tend to form a greater percentage of the rental population (Andrews et al., 2011). Worldbank (1993) highlights that rental housing is an important alternative to owner-occupied housing and stresses that rent control can distort housing and labor market outcomes. Arnott (1995) reviews the literature on rent control. Justifications for the use of rent control include providing affordable housing services and supporting rent stabilization as well as balancing bargaining power inequality and addressing information asymmetries between landlords and tenants. Arguments against rent control emphasize that its implementation can contribute to rental housing underinvestment, insufficient spending on rental housing improvement and maintenance, inferior labor market outcomes, rental price distortion as well as inefficient resource allocation and distribution, i.e., consumers do not necessarily get the desired rental housing quality and size at the controlled price (e.g., Worldbank, 1993; Arnott, 1995; Sims, 2007; Andrews et al., 2011). Menard \& Sellem (2010) indicate that subsidized tenants tend to accept lower-paid jobs and may be unemployed longer, as they are reluctant to give up relatively favorable tenancy conditions.

ECB (2003) argues that relocating tenants tend to endure the most of rental price corrections in a rent-controlled market. Arnott \& Igarashi (2000) show that looser and tighter rent control regimes contribute to social welfare gains and losses, respectively. Rental housing market reform implementation is delayed if the revised rules are only applied to new tenancy agreements (ECB, 2003). According to Worldbank (1993), research suggests that the public sector is less efficient than the private sector in providing housing services. Hughes \& McCormick (1981) and OECD (2011) propose that more market-oriented housing assistance, such as portable housing allowances, are unlikely to hinder residential mobility to the same extent as and are preferable to the provision of subsidized housing services by the government or government-sponsored entities. Kangasharju (2010) studies the impact of housing allowances on the rent paid by subsidized housing residents; he discovers that an extra euro of housing allowance tends to increase the rent paid by up to 70 cents and therefore leaves a limited amount for housing-unrelated spending.

Relaxing rent control and tenant-landlord regulations can improve rental housing investment and residential mobility (e.g., ECB, 2003; OECD, 2011). To enhance residential mobility, OECD (2011) suggests relaxing rental housing regulations, harmonizing subsidized and unsubsidized rental housing regulations and harmonizing the fiscal treatment of owner-occupied and rental housing.

\subsection{Social Inequality and Housing Market Outcomes}

Social inclusion can promote societal progress (Andrews et al., 2011). Social inequality is characterized by uneven resource distribution. Resource-constrained consumers adjust housing consumption to prices. Inferior housing is an alternative to superior housing, and informal housing is an alternative to unaffordable formal housing. Informal settlements, which tend to be associated with poverty, often suffer from property right insecurity, housing tenure uncertainty, a lack of housing-related infrastructure, inferior quality and crime. Inequality concerns can motivate housing market interventions. Promoting property rights, tenure security and housing-related infrastructure, for example, in informal settlements, can contribute to the functioning of the housing market. Economic progress and policy reform aimed at increasing the functioning of the housing market can contribute to superior housing market outcomes in terms of prices, sizes and quality (Worldbank, 1993). Housing provides shelter and allows for wealth accumulation, and reform aimed at transforming informal into formal settlements is likely to give rise to social friction if gentrification is not avoided.

Fitzpatrick \& Stephens (2007) find that homelessness is lower in economies where social welfare and affordable housing are less limited. Galster (2007) reviews the literature on the interplay between neighborhood social diversity and social equity and finds that there is no clear evidence that socially mixed neighborhoods are sufficient to combat social inequality. Socially disadvantaged households may be incentivized to engage in housing. Policies aimed at facilitating access to credit for these households can enable them to afford housing 
(Worldbank, 1993). Housing-related fiscal policies can also influence the social mix of a neighborhood. Andrews et al. (2011) argue that efficient subsidized housing eligibility and allocations policies minimize deadweight losses. Galster (2007) stresses that, contingent on the combination of prevailing neighborhood effects, the targeted neighborhood social diversity can be in the range of equally mixed and completely segregated. This finding demonstrates that housing-related policies aimed at neighborhood social diversity to combat social inequality might be justified only under a confined set of prevailing neighborhood effects.

\subsection{Housing Supply and Housing Market Outcomes}

Property rights allow for property exchanges on a legal and enforceable basis. A lack of legal security as well as procedural and administrative bottlenecks in housing supply shape housing market outcomes. Informal settlements may flourish if legal security is unsound. Winkler (2016a) reviews the literature on housing supply. The nature of housing supply is found to help explain house price developments (e.g., Glaeser et al., 2008; Gyourko, 2009; Grimes \& Aitken, 2010), housing affordability (e.g., Glaeser \& Gyourko, 2002; Meen, 2011), cross-location income inequality (e.g., Glaeser et al., 2006; Saks, 2008), labor economics (e.g., Cannari et al., 2000; Andrews \& Caldera Sanchez, 2011) and housing-related policy reform success (e.g., Swank et al., 2002; Hilber \& Turner, 2014). Housing supply reform has great potential to enable the housing market to work better (Worldbank, 1993). However, care needs to be taken when changing housing supply-related policies, as interventions can affect land prices, building costs, housing quality, housing suppliers' efficiency, housing supply flexibility and housing prices (e.g., Worldbank, 1993; Andrews, 2010). A cost and benefit analysis is therefore advised before implementing housing supply-related policies because changes can influence housing affordability, social inclusion, labor economics, resources consumption and environmental pollution (e.g., Worldbank, 1993; Glaeser \& Gyourko, 2002; Andrews, 2010; Meen, 2011).

Housing sector performance and the associated effects on societal progress and wellbeing may be augmented by better adjustment of housing supply to demand. Housing supply flexibility can be supported by modest housing investment constraints and construction impediments (Jaccard, 2011), appropriate building codes, infrastructure standards and land-use regulations (e.g., Worldbank, 1993; Mayer \& Somerville, 2000; Vermeulen \& Rouwendal, 2007), efficient licensing processes, better incentives to release land for residential development (Andrews et al., 2011), and superior housing finance conditions (Winkler, 2016a). Policies targeted at addressing supply shortages could tackle building industry entry barriers, monopolistic and insufficient housing market competition, deficient residential land provision and inappropriate housing-related infrastructure supply (e.g., Saiz, 2010; Andrews et al., 2011). Worldbank (1993) highlights that private sector housing suppliers tend to operate more efficiently than public sector housing suppliers, and advises governments to limit their role as housing service providers and facilitate the private sector's role in the housing market.

\subsection{Rational for Consumer Debt Restructuring}

Policies aimed at restoring borrowers' financial position, creditworthiness and debt servicing capacity can affect housing market outcomes. Pressures on societal progress and wellbeing arising from unsustainable consumer indebtedness can necessitate consumer debt restructuring (e.g., Eggertsson \& Krugman, 2012; Laeven \& Laryea, 2014). The goal of restructuring should be to ensure that the present value of debt after restructuring is lower than before. This process may offer an alternative to borrower default and foreclosure, and can include credit terms and conditions changes as well as the imposition of a moratorium on debt servicing and foreclosure. Lenders typically carry the associated losses, and financial stability can be at risk if the impairment of the lenders' financial position is substantial. Aspects such as the available room for fiscal maneuver, consumer recourse to social welfare (Igan et al., 2014) as well as the level of contraction in consumer spending may influence government involvement in consumer debt restructuring.

Policy design shapes the fiscal outlay. The government may grant consumer loan guarantees, which imply limited upfront fiscal outlay but contingent liabilities (Claessens et al., 2014). The fiscal outlay associated with voluntary settlements between lenders and borrowers might be low. Mandatory government sponsored consumer debt restructuring programs can strain public resources, and sound principles should guide their layout. In this context, policy makers should consider the legal and institutional framework, limit public sector losses, protect critical financial services, minimize sustained excessive risk taking by borrowers and lenders, offer borrowers and lenders enough participation incentives and set the basis for economic recovery (e.g., Igan et al., 2014; Laeven \& Laryea, 2014). In other words, incompatible interests need to be reconciled. For the policy program to be effective, timing can be critical. Laeven \& Laryea (2014) suggest implementing a program once economic indicators stabilize and an effective resolution and recovery regime is operational.

To avoid a credit crunch, lenders need sufficient capital to absorb the losses associated with consumer debt 
restructuring (Shleifer \& Vishny, 2011). To handle insufficiently capitalized lenders, policy makers need to employ effective resolution and recovery measures (Landier \& Ueda, 2014). The redistribution of resources associated with government sponsored debt restructuring can give rise to social friction, which may be why this option is heavily debated, rarely used and implemented with delay (Igan et al., 2014). However, delays in financial and operational restructuring as well as the handling of nonperforming loans on the balance sheet of lenders can hamper economic recovery (Claessens et al., 2014).

\section{Conclusion}

By summarizing the key findings in the existing theoretical and empirical literature, this study adds to our understanding of the complex dynamics between housing, finance, policy and the wider economy; it also examines housing-related policies and their effects. The presented real, legislative and financial circuits suggest that an enabling strategy for housing can support societal progress and wellbeing. To improve the functioning of the housing market, it is imperative that a coordinating authority takes steps to reconcile the mutually incompatible interests of the various housing market stakeholders and arrange for concerted policy and institutional reforms. An enabling strategy for housing should be based on superior knowledge about the housing sector's performance, its contribution to the broader economic performance and the success of housing-related policies. Evidence-based housing-related policy setting furthermore necessitates the compilation, analysis and interpretation of reliable housing and economic indicators.

Property rights are an important enabling instrument, as they are a prerequisite for formal property exchanges, housing finance and housing-related policies. Unenforced policies are unlikely to bite; enforcement matters for encouraging the housing market stakeholders to adhere to principles. Communication, too, is crucial; policy actions may be more effective if the stakeholders know in advance the reasons for the change. The promotion of market-oriented housing supply and finance solutions may be desirable if concerns over housing affordability arise. To hamper mortgage supply, mitigating their preferential policy treatment might be sensible. In addition, countercyclical prudential policies can be a reasonable way to confine consumer credit risk. To foster affordable housing and labor mobility, it may be worthwhile to encourage a viable rental housing market. The goal of an enabling strategy for housing should be the achievement of an efficient, socially inclusive and sustainable framework for housing and housing-related infrastructure.

Regular and critical reviews of the housing sector's operational framework and the sectoral contribution to the achievement of economic, financial, social and environmental objectives should be standard, as they allow for the identification of housing market misallocation, dislocation and reform needs. Evaluating the effects of differences in the set of housing-related policies on housing market outcomes, societal progress and wellbeing is impossible without reliable, accurate and timely data on both formal and informal housing sector performance as well as economic outcomes. Addressing existing data deficiencies is thus an important element of an enabling strategy for housing. This facilitates not only evidence-based housing-related policy setting, but also empirical research on the success and interactions of different housing-related policies, the optimal sequencing of policy reform and the implications of housing-related policies for consumers from different ethnic groups; the empirical research results can also help policy makers in the policy setting.

Advances in technology and financial liberalization change the way consumers secure finance. Leveraging these changes can be destabilizing without adequate regulation and supervision. The growing importance of unregulated finance solutions can undermine the impact of regulatory oversight. In addition, innovative underwriting concepts based on newly developed, data-driven algorithms tend to remain untested through full credit cycles. Future research could address how the supervisory system and financial industry should react to trends such as increasing cyber-security concerns and the growing importance of unregulated finance solutions and data-driven underwriting concepts. Providing regulatory clarity and direction can support sustainable access to credit, especially for underserved consumers. Market-oriented housing finance solutions have great potential to enable the housing market to work better. Research could investigate the effects of the emergence of innovative finance alternatives for the interplay of the housing market and the wider economy.

\section{Acknowledgments}

I thank Prof. Dr. Markus Rudolf (WHU-Otto Beisheim School of Management, Germany) as well as Prof. Dr. Jürgen Weigand (WHU-Otto Beisheim School of Management, Germany) who assisted in commenting on the manuscript.

\section{References}

Abiad, A., Balakrishnan, R., Koeva Brooks, P., Leigh, D., \& Tytell, I. (2014). What's the damage? Medium-term output dynamics after financial crises. In S. Claessens, M. A. Kose, L. Laeven, \& F. Valencia, (Eds.), 
Financial crises: causes, consequences, and policy responses (pp. 277-307). International Monetary Fund.

Abiad, A., Dell'Ariccia, G., \& Li, G. B. (2011). Creditless recoveries. Working Paper 11/58, International Monetary Fund. https://doi.org/10.5089/9781455221028.001

Abiad, A., Detragiache, E., \& Tressel, T. (2010). A new database of financial reforms. IMF Staff Papers, 57(2), 281-302. https://doi.org/10.1057/imfsp.2009.23

Ahearne, A. G., Ammer, J., Doyle, B. M., Kole, L., \& Martin, R. F. (2005). Monetary policy and house prices: a cross-country study. International Finance Discussion Paper 841, Board of Governors of the Federal Reserve System. https://doi.org/10.2139/ssrn.816946

Almeida, H., Campello, M., \& Liu, C. (2006). The financial accelerator: evidence from international housing markets. Review of Finance, 10(3), 321-352. https://doi.org/10.1007/s10679-006-9004-9

Alpanda, S., \& Zubairy, S. (2016). Housing and tax policy. Journal of Money, Credit and Banking, 48(2-3), 485-512. https://doi.org/10.1111/jmcb.12307

Andrews, D. (2010). Real house prices in OECD countries: the role of demand shocks and structural and policy factors. Economics Department Working Paper 831, Organisation for Economic Co-operation and Development. https://doi.org/10.1787/5km33bqzhbzr-en

Andrews, D., \& Caldera Sanchez, A. (2011). Drivers of homeownership rates in selected OECD countries. Economics Department Working Paper 849, Organisation for Economic Co-operation and Development. https://doi.org/10.1787/5kgg9mcwc7jf-en

Andrews, D., \& Caldera Sanchez, A. (2011). To move or not to move: what drives residential mobility rates in the OECD? Economics Department Working Paper 846, Organisation for Economic Co-operation and Development. https://doi.org/10.1787/5kghtc7kzx21-en

Andrews, D., Caldera Sanchez, A., \& Johansson, A. (2011). Housing markets and structural policies in OECD countries. Economics Department Working Paper 836, Organisation for Economic Co-operation and Development. https://doi.org/10.1787/5kgk8t2k9vf3-en

Aoki, K., Proudman, J., \& Vlieghe, G. (2004). House prices, consumption, and monetary policy: a financial accelerator approach. Journal of Financial Intermediation, 13(4), 414-435. https://doi.org/10.1016/j.jfi.2004.06.003

Arnott, R. (1995). Time for revisionism on rent control? Journal of Economic Perspectives, 9(1), 99-120. https://doi.org/10.1257/jep.9.1.99

Arnott, R., \& Igarashi, M. (2000). Rent control, mismatch costs and search efficiency. Regional Science and Urban Economics, 30(3), 249-288. https://doi.org/10.1016/s0166-0462(00)00033-8

Barcelo, C. (2006). Housing tenure and labour mobility: a comparison across European countries. Research Paper 603, Banco de Espana. https://doi.org/10.2139/ssrn.383520

Barth, J. R., Levine, R., \& Caprio, G. (2012). Guardians of finance: making regulators work for us. Cambridge, MA: MIT Press.

Bean, C., Broda, C., Ito, T., \& Kroszner, R. (2015). Low for long? Causes and consequences of persistently low interest rates. Geneva Reports on the World Economy 17, International Center for Monetary and Banking Studies, Geneva.

Bernanke, B., \& Gertler, M. (1989). Agency costs, net worth, and business fluctuations. American Economic Review, 79(1), 14-31.

Bernanke, B., \& Gertler, M. (1995). Inside the black box: the credit channel of monetary policy transmission. Journal of Economic Perspectives, 9(4), 27-48. https://doi.org/10.1257/jep.9.4.27

Bernanke, B., Gertler, M., \& Gilchrist, S. (1996). The financial accelerator and the flight to quality. Review of Economics and Statistics, 78(1), 1-15. https://doi.org/10.2307/2109844

Blanchard, O. J. (1985). Debt, deficits, and finite horizons. Journal of Political Economy, 93(2), $223-247$. https://doi.org/10.1086/261297

Buiter, W. H. (2010). Housing wealth isnt wealth. Economics: The Open-Access, Open-Assessment E-Journal, 4(2010-22). https://doi.org/10.5018/economics-ejournal.ja.2010-22

Calza, A., Monacelli, T., \& Stracca, L. (2013). Housing finance and monetary policy. Journal of the European Economic Association, 11(S1), S101-S122. https://doi.org/10.1111/j.1542-4774.2012.01095.x 
Cameron, G., \& Muellbauer, J. (1998). The housing market and regional commuting and migration choices. Scottish Journal of Political Economy, 45(4), 420-446. https://doi.org/10.1111/1467-9485.00106

Cannari, L., Nucci, F., \& Sestito, P. (2000). Geographic labour mobility and the cost of housing: evidence from Italy. Applied Economics, 32(14), 1899-1906. https://doi.org/10.1080/000368400425116

Caprio, G., \& Honohan, P. (2001). Finance for growth: policy choices in a volatile world. Policy Research Report, World Bank, Washington, DC. https://doi.org/10.1596/0-1952-1605-9

Carroll, C. D., \& Kimball, M. S. (1996). On the concavity of the consumption function. Econometrica, 64(4), 981-992. https://doi.org/10.2307/2171853

Claessens, S., \& Kose, M. A. (2014). Financial crises: explanations, types, and implications. In S. Claessens, M. A. Kose, L. Laeven, \& F. Valencia (Eds.), Financial crises: causes, consequences, and policy responses (pp. 3-59). International Monetary Fund.

Claessens, S., Kose, M. A., Laeven, L., \& Valencia, F. (2014). Financial crises: causes, consequences, and policy responses. International Monetary Fund.

Claessens, S., Kose, M. A., \& Terrones, M. E. (2012). How do business and financial cycles interact? Journal of International Economics, 87(1), 178-190. https://doi.org/10.1016/j.jinteco.2011.11.008

Claessens, S., Pazarbasioglu, C., Laeven, L., Dobler, M., Valencia, F., Nedelescu, O., \& Seal, K. (2014). Crisis management and resolution: early lessons from the 2007-09 financial crisis. In S. Claessens, M. A. Kose, L. Laeven, \& F. Valencia (Eds.), Financial crises: causes, consequences, and policy responses (pp. 461-488). International Monetary Fund.

Coenen, G., Erceg, C. J., Freedman, C., Furceri, D., Kumhof, M., Lalonde, R., ... Int Veld, J. (2012). Effects of fiscal stimulus in structural models. American Economic Journal: Macroeconomics, 4(1), 22-68. https://doi.org/10.1257/mac.4.1.22

Collyns, C., \& Senhadji, A. (2002). Lending booms, real estate bubbles and the Asian crisis. Working Paper 02/20, International Monetary Fund. https://doi.org/10.5089/9781451843859.001

Coulson, N. E., \& Fisher, L. M. (2009). Housing tenure and labor market impacts: the search goes on. Journal of Urban Economics, 65(3), 252-264. https://doi.org/10.1016/j.jue.2008.12.003

Dabla-Norris, E., Ho, G., \& Kyobe, A. (2016). Structural reforms and productivity growth in emerging market and developing economies. Working Paper 16/15, International Monetary Fund. https://doi.org/10.5089/9781498306560.001

Davey, M. (2001). Mortgage equity withdrawal and consumption. Quarterly Bulletin Spring 2001, Bank of England.

Deaton, A. (1992). Understanding consumption. Oxford University Press, Oxford. https://doi.org/10.1093/0198288247.001.0001

Denton, J. A. (1990). Society and the official world: a reintroduction to sociology. Lanham, MD: Rowman and Littlefield Publishers.

DiPasquale, D., \& Glaeser, E. L. (1999). Incentives and social capital: are homeowners better citizens? Journal of Urban Economics, 45(2), 354-384. https://doi.org/10.1006/juec.1998.2098

Drudi, F., Koehler-Ulbrich, P., Protopapa, M., Slacalek, J., Soerensen, C. K., Wolswijk, G., ... Lukovic, V. (2009). Housing finance in the euro area. Occasional Paper 101, Task Force of the Monetary Policy Committee of the European System of Central Banks, European Central Bank.

ECB. (2003). Structural factors in the EU housing markets. Report, Task Force on Housing of the Monetary Policy Committee of the European System of Central Banks, European Central Bank.

ECB. (2016). Transmission mechanism of monetary policy. Retrieved from: https://www.ecb.europa.eu/mopo/intro/transmission/html/index.en.html

Eggertsson, G. B., \& Krugman, P. (2012). Debt, deleveraging, and the liquidity trap: a Fisher-Minsky-Koo approach. Quarterly Journal of Economics, 127(3), 1469-1513. https://doi.org/10.1093/qje/qjs023

Farhi, E., \& Tirole, J. (2012). Collective moral hazard, maturity mismatch, and systemic bailouts. American Economic Review, 102(1), 60-93. https://doi.org/10.1257/aer.102.1.60

Ferreira, F., Gyourko, J., \& Tracy, J. (2012). Housing busts and household mobility: an update. Federal Reserve Bank of New York Economic Policy Review, 18(3), 1-15. 
Fitzpatrick, S., \& Stephens, M. (2007). An international review of homelessness and social housing policy. Communities and Local Government Publications, Department for Communities and Local Government, London.

Flatau, P., Forbes, M., \& Hendershott, P. H. (2003). Homeownership and unemployment: the roles of leverage and public housing. Working Paper 10021, National Bureau of Economic Research. https://doi.org/10.3386/w10021

Friedman, M. (1957). The permanent income hypothesis. A theory of the consumption function (pp. 20-37). Princeton University Press.

Galster, G. (2007). Neighbourhood social mix as a goal of housing policy: a theoretical analysis. International Journal of Housing Policy, 7(1), 19-43. https://doi.org/10.1080/14616710601132526

Gervais, M. (2002). Housing taxation and capital accumulation. Journal of Monetary Economics, 49(7), 1461-1489. https://doi.org/10.1016/s0304-3932(02)00172-1

Girouard, N., Kennedy, M., van den Noord, P., \& Andre, C. (2006). Recent house price developments: the role of fundamentals. Economics Department Working Paper 475, Organisation for Economic Co-operation and Development. https://doi.org/10.1787/864035447847

Glaeser, E. L., \& Gyourko, J. (2002). The impact of zoning on housing affordability. Working Paper 8835, National Bureau of Economic Research. https://doi.org/10.3386/w8835

Glaeser, E. L., Gyourko, J., \& Saiz, A. (2008). Housing supply and housing bubbles. Journal of Urban Economics, 64(2), 198-217. https://doi.org/10.1016/j.jue.2008.07.007

Glaeser, E. L., Gyourko, J., \& Saks, R. E. (2006). Urban growth and housing supply. Journal of Economic Geography, 6(1), 71-89. https://doi.org/10.1093/jeg/lbi003

Glaeser, E. L., \& Shapiro, J. M. (2003). The benefits of the home mortgage interest deduction. Tax policy and the economy, 17, 37-82. Cambridge, MA: MIT Press. https://doi.org/10.1086/tpe.17.20140504

Grimes, A., \& Aitken, A. (2010). Housing supply, land costs and price adjustment. Real Estate Economics, 38(2), 325-353. https://doi.org/10.1111/j.1540-6229.2010.00269.x

Gyourko, J. (2009). Housing supply. Annual Review of Economics, 1(3), 295-318. https://doi.org/10.1146/annurev.economics.050708.142907

Hanson, A. (2012). Size of home, homeownership, and the mortgage interest deduction. Journal of Housing Economics, 21(3), 195-210. https://doi.org/10.1016/j.jhe.2012.06.001

Haurin, D. R., \& Gill, H. L. (2002). The impact of transaction costs and the expected length of stay on homeownership. Journal of Urban Economics, 51(3), 563-584. https://doi.org/10.1006/juec.2001.2258

Hiebert, P., \& Sydow, M. (2011). What drives returns to euro area housing? Evidence from a dynamic dividend-discount model. Journal of Urban Economics, 70(2-3), 88-98. https://doi.org/10.1016/j.jue.2011.03.001

Hilber, C. A. L., \& Turner, T. M. (2014). The mortgage interest deduction and its impact on homeownership decisions. Review of Economics and Statistics, 96(4), 618-637. https://doi.org/10.1162/rest_a_00427

Hofmann, B. (2001). The determinants of private sector credit in industrialised countries: do property prices matter? Working Paper 108, Bank for International Settlements. https://doi.org/10.2139/ssrn.847404

Huefner, F., \& Lundsgaard, J. (2007). The Swedish housing market. Economics Department Working Paper 559, Organisation for Economic Co-operation and Development. https://doi.org/10.1787/175230504175

Hughes, G., \& McCormick, B. (1981). Do council housing policies reduce migration between regions? Economic Journal, 91(364), 919-937. https://doi.org/10.2307/2232500

Iacoviello, M. (2005). House prices, borrowing constraints, and monetary policy in the business cycle. American Economic Review, 95(3), 739-764. https://doi.org/10.1257/0002828054201477

Igan, D., Leigh, D., Simon, J., \& Topalova, P. (2014). Dealing with household debt. In S. Claessens, M. A. Kose, L. Laeven, \& F. Valencia, (Eds.), Financial crises: causes, consequences, and policy responses (pp. 547-592). International Monetary Fund.

Jaccard, I. (2011). Asset pricing and housing supply in a production economy. B.E. Journal of Macroeconomics, 11(1), 1-38. https://doi.org/10.2202/1935-1690.1685 
Kangasharju, A. (2010). Housing allowance and the rent of low-income households. Scandinavian Journal of Economics, 112(3), 595-617. https://doi.org/10.1111/j.1467-9442.2010.01615.x

Kannan, P., Scott, A., \& Terrones, M. E. (2014). From recession to recovery: how soon and how strong? In S. Claessens, M. A. Kose, L. Laeven, \& F. Valencia (Eds.), Financial crises: causes, consequences, and policy responses (pp. 239-274). International Monetary Fund.

Kasparova, D., \& White, M. (2001). The responsiveness of house prices to macroeconomic forces: a cross-country comparison. European Journal of Housing Policy, 1(3), 385-416. https://doi.org/10.1080/14616710110091561

Keen, M., Klemm, A., \& Perry, V. (2010). Tax and the crisis. Fiscal Studies, 31(1), 43-79. https://doi.org/10.1111/j.1475-5890.2010.00107.x

Keynes, J. M. (1936). The general theory of employment, interest, and money. London: Macmillan.

King, M. (1994). Debt deflation: Theory and evidence. European Economic Review, 38(3-4), 419-445. https://doi.org/10.1016/0014-2921(94)90083-3

Kishan, R. P., \& Opiela, T. P. (2006). Bank capital and loan asymmetry in the transmission of monetary policy. Journal of Banking and Finance, 30(1), 259-285. https://doi.org/10.1016/j.jbankfin.2005.05.002

Kiyotaki, N., \& Moore, J. (1997). Credit cycles. Journal of Political Economy, 105(2), 211-248. https://doi.org/10.1086/262072

Kuttner, K., \& Shim, I. (2012). Taming the real estate beast: the effects of monetary and macroprudential policies on housing prices and credit. In A. Heath, F. Packer, \& C. Windsor (Eds.), Property markets and financial stability (pp. 231-259). Sydney. Reserve Bank of Australia.

La Porta, R., Lopez-de Silanes, F., Shleifer, A., \& Vishny, R. W. (1998). Law and finance. Journal of Political Economy, 106(6), 1113-1155. https://doi.org/10.1086/250042

Laeven, L., \& Laryea, T. (2014). Principles of household debt restructuring. In S. Claessens, M. A. Kose, L. Laeven, \& F. Valencia (Eds.), Financial crises: causes, consequences, and policy responses (pp. 527-545). International Monetary Fund.

Laeven, L., \& Valencia, F. (2013). Systemic banking crises database. IMF Economic Review, 61(2), 225-270. https://doi.org/10.1057/imfer.2013.12

Landier, A., \& Ueda, K. (2014). The economics of bank restructuring: understanding the options. In S. Claessens, M. A. Kose, L. Laeven, \& F. Valencia, (Eds.), Financial crises: causes, consequences, and policy responses (pp. 489-525). International Monetary Fund.

Levine, R. (1999). Law, finance, and economic growth. Journal of Financial Intermediation, 8(1-2), 8-35. https://doi.org/10.1006/jfin.1998.0255

Levine, R. (2005). Finance and growth: theory and evidence. In P. Aghion \& S. N. Durlauf (Eds.), Handbook of economic growth, 1, part A, chapter 12, pp. 865-934. Amsterdam: Elsevier. https://doi.org/10.1016/s1574-0684(05)01012-9

Lown, C., \& Morgan, D. P. (2006). The credit cycle and the business cycle: new findings using the loan officer opinion survey. Journal of Money, Credit and Banking, 38(6), 1575-1597. https://doi.org/10.1353/mcb.2006.0086

Lundborg, P., \& Skedinger, P. (1999). Transaction taxes in a search model of the housing market. Journal of Urban Economics, 45(2), 385-399. https://doi.org/10.1006/juec.1998.2103

Maclennan, D., Muellbauer, J., \& Stephens, M. (1998). Asymmetries in housing and financial market institutions and EMU. Oxford Review of Economic Policy, 14(3), 54-80. https://doi.org/10.1093/oxrep/14.3.54

Mayer, C. J., \& Somerville, C. T. (2000). Land use regulation and new construction. Regional Science and Urban Economics, 30(6), 639-662. https://doi.org/10.1016/s0166-0462(00)00055-7

Meen, G. (2011). A long-run model of housing affordability. Housing Studies, 26(7-8), 1081-1103. https://doi.org/10.1080/02673037.2011.609327

Menard, S., \& Sellem, F. (2010). How does social housing affect the rate of equilibrium unemployment? Working Paper.

Mian, A., Rao, K., \& Sufi, A. (2013). Household balance sheets, consumption, and the economic slump. Quarterly Journal of Economics, 128(4), 1687-1726. https://doi.org/10.1093/qje/qjt020 
Mian, A., Sufi, A., \& Trebbi, F. (2015). Foreclosures, house prices, and the real economy. Journal of Finance, 70(6), 2587-2633. https://doi.org/10.1111/jofi.12310

Mishkin, F. S. (1978). The household balance sheet and the great depression. Journal of Economic History, 38(4), 918-937. https://doi.org/10.1017/s0022050700087167

Mishkin, F. S. (2007). Housing and the monetary transmission mechanism. Working Paper 13518, National Bureau of Economic Research. https://doi.org/10.3386/w13518

Modigliani, F. (1971). Monetary policy and consumption: linkages via interest rate and wealth effects in the FMP model. Consumer Spending and Monetary Policy: The Linkages, 5, 9-84. Nantucket Island, MA. Federal Reserve Bank of Boston.

Modigliani, F., \& Brumberg, R. (1954). Utility analysis and the consumption function. In K. K. Kurihara (Ed.), Post-Kenesian economics (pp. 388-436). New Brunswick, NJ: Rutgers University Press.

Muellbauer, J. (1992). Anglo-German differences in housing market dynamics. European Economic Review, 36(2), 539-548. https://doi.org/10.1016/0014-2921(92)90111-9

Muellbauer, J., \& Murphy, A. (1997). Booms and busts in the UK housing market. Economic Journal, 107(445), 1701-1727. https://doi.org/10.1111/j.1468-0297.1997.tb00076.x

Munch, J. R., Rosholm, M., \& Svarer, M. (2006). Are homeowners really more unemployed? Economic Journal, 116(514), 991-1013. https://doi.org/10.1111/j.1468-0297.2006.01120.x

Noord, P. V. D. (2003). Tax incentives and house price volatility in the euro area. Economics Department Working Paper 356, Organisation for Economic Co-operation and Development. https://doi.org/10.1787/410243688730

OECD. (2011). Housing and the economy: policies for renovation. Economic policy reforms 2011: going for growth (pp. 181-203). Organisation for Economic Co-operation and Development. https://doi.org/10.1787/growth-2011-46-en

Ortalo-Magne, F., \& Rady, S. (2006). Housing market dynamics: on the contribution of income shocks and credit constraints. Review of Economic Studies, 73(2), 459-485. https://doi.org/10.1111/j.1467-937x.2006.383_1.x

Oswald, A. J. (1996). A conjecture on the explanation for high unemployment in the industrialized nations: part 1. Warwick Economic Research Paper 475, University of Warwick, Coventry.

Poterba, J., \& Sinai, T. (2008). Tax expenditures for owner-occupied housing: deductions for property taxes and mortgage interest and the exclusion of imputed rental income. American Economic Review, 98(2), 84-89. https://doi.org/10.1257/aer.98.2.84

Poterba, J. M. (1992). Taxation and housing: old questions, new answers. American Economic Review, 82(2), 237-242.

Poterba, J. M., \& Noguchi, Y. (1994). Housing markets in the United States and Japan. A National Bureau of Economic Research Conference Report. University of Chicago Press, Chicago. https://doi.org/10.7208/chicago/9780226590202.001.0001

Reinhart, C. M., \& Rogoff, K. S. (2009). This time Is different: eight centuries of financial folly. Princeton, New Jersey: Princeton University Press.

Rosen, H. S. (1979). Housing decisions and the U.S. income tax. Journal of Public Economics, 11(1), 1-23. https://doi.org/10.1016/0047-2727(79)90042-2

Rupert, P., \& Wasmer, E. (2012). Housing and the labor market: time to move and aggregate unemployment. Journal of Monetary Economics, 59(1), 24-36. https://doi.org/10.1016/j.jmoneco.2011.10.008

Saiz, A. (2010). The geographic determinants of housing supply. Quarterly Journal of Economics, 125(3), 1253-1296. https://doi.org/10.1162/qjec.2010.125.3.1253

Saks, R. E. (2008). Job creation and housing construction: constraints on metropolitan area employment growth. Journal of Urban Economics, 64(1), 178-195. https://doi.org/10.1016/j.jue.2007.12.003

Schularick, M., \& Taylor, A. M. (2012). Credit booms gone bust: monetary policy, leverage cycles, and financial crises, 1870-2008. American Economic Review, 102(2), 1029-1061. https://doi.org/10.1257/aer.102.2.1029

Shi, S., Jou, J. B., \& Tripe, D. (2014). Can interest rates really control house prices? Effectiveness and implications for macroprudential policy. Journal of Banking and Finance, 47, 15-28. https://doi.org/10.1016/j.jbankfin.2014.06.012 
Shleifer, A., \& Vishny, R. (2011). Fire sales in finance and macroeconomics. Journal of Economic Perspectives, 25(1), 29-48. https://doi.org/10.1257/jep.25.1.29

Shleifer, A., \& Vishny, R. W. (1992). Liquidation values and debt capacity: a market equilibrium approach. Journal of Finance, 47(4), 1343-1366. https://doi.org/10.1111/j.1540-6261.1992.tb04661.x

Sims, D. P. (2007). Out of control: what can we learn from the end of Massachusetts rent control? Journal of Urban Economics, 61(1), 129-151. https://doi.org/10.1016/j.jue.2006.06.004

Swank, J., Kakes, J., \& Tieman, A. F. (2002). The housing ladder, taxation, and borrowing constraints. Working Paper 2002-9, De Nederlandsche Bank.

Van Ommeren, J., \& Van Leuvensteijn, M. (2005). New evidence of the effect of transaction costs on residential mobility. Journal of Regional Science, 45(4), 681-702. https://doi.org/10.1111/j.0022-4146.2005.00389.x

Vermeulen, W., \& Rouwendal, J. (2007). Housing supply and land use regulation in the Netherlands. Tinbergen Institute Discussion Paper 2007-058/3, Tinbergen Institute, Amsterdam. https://doi.org/10.2139/ssrn.1003955

Winkler, S. (2016a). Divergence in the nature of new housing supply. Working Paper. https://doi.org/10.2139/ssrn.2833492

Winkler, S. (2016b). Empirical evidence of the housing wealth effect. Working Paper. https://doi.org/10.2139/ssrn.2695778

Worldbank. (1993). Housing: enabling markets to work. Policy Paper, World Bank, Washington, DC. https://doi.org/10.1596/0-8213-2434-9

\section{Note}

Note 1. Worldbank (1993) states that each dollar of housing investment produces to two dollars of economic activity in other sectors, and one more job in residential building gives rise to two other jobs. Maclennan et al. (1998) stress that the building industry provides between five and ten percent of the European employment. Gross fixed capital formation in dwellings was, on average, in the range of 4.4 and 9.4 percent of GDP in the past 45 years in Australia, Belgium, Canada, Denmark, Finland, France, Germany, Italy, Japan, Sweden, Switzerland, the Netherlands, the United Kingdom and the United States. Alone the housing wealth of households accounts for up to four percent of GDP in these countries. For countries where gross national product per capita is similar, housing investment tends to be larger in jurisdictions where urbanization rates are higher (Worldbank, 1993).

\section{Copyrights}

Copyright for this article is retained by the author(s), with first publication rights granted to the journal.

This is an open-access article distributed under the terms and conditions of the Creative Commons Attribution license (http://creativecommons.org/licenses/by/4.0/). 